\title{
Evaluation of protein expression and DNA methylation profiles detected by pyrosequencing in invasive breast cancer
}

\author{
I. ZMETAKOVA ${ }^{1}$, L. DANIHEL ${ }^{2,3}$, B. SMOLKOVA ${ }^{1}$, M. MEGO ${ }^{4}$, V. KAJABOVA ${ }^{1}$, T. KRIVULCIK ${ }^{1}$, I. RUSNAK ${ }^{5}$, B. RYCHLY', D. DANIS ${ }^{6}$, V. REPISKA ${ }^{7}$, \\ P. BLASKO ${ }^{8}$, M. KARABA ${ }^{9}$, J. BENCA ${ }^{9}$, J. PECHAN ${ }^{9,10}$, I. FRIDRICHOVA $^{1, *}$
}

\begin{abstract}
${ }^{1}$ Laboratory of Cancer Genetics, Cancer Research Institute of SAS, Bratislava, Slovak Republic; ${ }^{2}$ Institute of Pathological Anatomy, Faculty of Medicine, Comenius University, University Hospital, Bratislava, Slovak Republic; ${ }^{3}$ Pathological-Anatomical Workplace, Health Care Surveillance Authority, Bratislava, Slovak Republic; ${ }^{42 n d}$ Department of Oncology, Faculty of Medicine, Comenius University, National Cancer Institute, Bratislava, Slovak Republic; ${ }^{51 s t}$ Department of Obstetrics and Gynaecology, Slovak Medical University, University Hospital, Bratislava, Slovak Republic; ${ }^{6}$ Cytopathos s.r.o., Bratislava, Slovak Republic; ${ }^{7}$ Institute of Medical Biology, Genetics and Clinical Genetics, Faculty of Medicine, Comenius University, University Hospital, Bratislava, Slovak Republic; ${ }^{8}$ Department of Gynaecology, General Hospital Inc., Malacky, Slovak Republic; ${ }^{9}$ Department of Surgical Oncology, National Cancer Institute, Bratislava, Slovak Republic; ${ }^{10}$ Department of Surgical Oncology, Slovak Medical University, National Cancer Institute, Bratislava, Slovak Republic
\end{abstract}

${ }^{*}$ Correspondence: Ivana.Fridrichova@savba.sk

Received June 12, 2012 / Accepted July 18, 2013

\begin{abstract}
Breast carcinoma is the most common cancer with high mortality caused by metastatic disease. New molecular biomarkers predicting the tumour's metastatic potential would therefore improve metastasis prevention and personalised care. The aim of the study was to investigate the relationship between DNA methylation levels in invasivity and metastasising associated genes with aberrant protein expression and also to evaluate whether a similar DNA methylation level is present in the tumour and circulating cell-free DNA for utilising plasma DNA methylation as prognostic biomarker. By using pyrosequencing, we analysed DNA methylation levels of 11 genes, namely APC, ADAM23, CXCL12, ESR1, PGR B, CDH1, RASSF1A, SYK, TIMP3, BRMS1 and SOCS1 in tumour, plasma and peripheral blood cells from 34 patients with primary breast cancer, as well as plasma and peripheral blood cells from 50 healthy controls. Simultaneously, the expression of related proteins in paraffin-embedded tumour samples was evaluated by immunohistochemistry. Statistical analysis was performed by SPSS statistics 15.0 software. Tumour DNA hypermethylation was found in most commonly methylated RASSF1A (71.9\%), APC (55.9\%), ADAM23 (38\%) and CXCL12 (34.4\%) genes with methylation levels up to 86, 86, 53 and 64\%, respectively. In tumours, significantly higher methylation levels were found in nine genes, compared with the patients' peripheral blood cell DNA. Furthermore, in patients methylation levels in peripheral blood cell DNA were significantly higher than in controls in CXCL12, ESR1 and TIMP3 genes, but the values did not exceed 15\%. On the other hand, no correlations were observed in patients between DNA methylation in tumours and cell-free plasma DNA. Moreover, in patients and controls nearly identical values of cumulative DNA methylation $(43.6 \% \pm 20.1 \mathrm{vs.} 43.7 \% \pm 15.0)$ were observed in plasma samples. A variable spectrum from high to none expressions presented in tumour tissues in all of the proteins evaluated, however in APC and CXCL12 genes a visible decreasing trend of mean DNA methylation level with increasing expression of the corresponding protein was observed. The DNA methylation profiles manifested in our group of breast carcinomas are cancer specific, but they are not the only cause that affects the silencing of evaluated genes and the decrease of relevant protein products. The clinical utility of DNA methylation testing in peripheral blood cell DNA for cancer diagnosis and therapy need to be further investigated.
\end{abstract}

Key words: breast cancer, protein expression, DNA methylation, invasivity and metastasising associated genes, pyrosequencing analysis

Breast cancer $(\mathrm{BC})$ is associated with a high mortality rate in women. Despite the fact that more targeted therapies have improved survival of patients with advanced stages; these tumours frequently relapse due to drug resistance mechanisms.
Thus a detailed study of DNA, RNA and protein alterations in mechanisms regulating the metastatic processes would improve metastasis prevention and personalised care [1]. It is generally accepted that in addition to genetic alterations, also 
abnormal epigenetic events are responsible for the development and progression of cancer. DNA methylation along with histone modifications and miRNA regulation generates the epigenetic control mechanism of germline and tissue specific gene expression. The results of many studies have shown that aberrant DNA methylation initiates carcinogenesis and promotes cancer progression by activating oncogenes, suppressing tumour suppressor genes and inducing chromosome instability. DNA methylation as an early event in breast carcinogenesis has been frequently studied in tumour samples, breast fluids and blood derivatives with the aim to find reliable, non-invasive cancer biomarkers. Numbers of genes have been reported as being methylated in breast and other cancers, with focus on potential clinical application of this information in cancer diagnosis, prognosis, and therapeutics [2]. DNA methylation of RASSF1A, RARbeta2 and APC genes in benign tissue was used for cancer risk prediction. The analysed genes had a higher methylation frequency in unaffected women at high risk for BC compared with those at low or intermediate risk [3]. Recent research has indicated that simultaneous assessment of multiple genes involved in different biological processes is more reasonable compared to single marker analysis. Several studies published panels of genes that in combination exhibited adequate sensitivity and specificity compared to single-marker analysis. Esteller and colleagues reported a sensitivity of $73 \%$ using a panel of four genes (GSTP1, BRCA1, CDH1 and P16) based on 45 $\mathrm{BC}$ tumours [4]. Pyrosequencing analyses of DNA methylation in promoters of four genes (RASSF1A, GSTP1, RAR $\beta$ and $C D H 1$ ) was investigated in a spectrum of neoplastic breast lesions in breast tissue samples. DNA methylation increased from normal tissue to hyperplasia and a significantly higher increase was found in invasive and in situ tumours for RASSF1A gene [5]. High sensitivity (84\%) and specificity (89\%) for detection of $B C$ was observed on using a panel of four genes (CCND2, HIN1, RASSF1 and TWIST) that was tested in 9 normal mammoplasty and 19 tumour specimens [6].

Several studies showed that disrupted protein expressions were associated with deregulation of DNA methylation of various genes in breast, lung, endometrial and other cancers [7-10].

As the potential of circulating cell-free DNA (cfDNA) was broadly recognised as a biomarker for early detection, diagnosis, prevention and treatment of cancer, huge effort has been concentrated on analysis of DNA methylation in serum/plasma samples [11-16]. Although numerous biomarker candidates have been reported, only few methylation based biomarkers, including SEPT9, VIM, SHOX2 and MGMT, have been adopted into clinical use for early detection of colorectal, lung and brain cancers [17]. Moreover, some systemic epigenetic changes were detected in peripheral blood cells in $\mathrm{BC}$ patients $[18,19]$. A recent article by $\mathrm{Li}$ and collaborators provided a comprehensive literature review of blood-based DNA methylation. The authors concluded that DNA methylation in peripheral blood of patients had a great potential to become useful as informative biomarkers of cancer risk and prognosis, yet large systematic and unbiased prospective studies considering biological plausibility and data analysis issues will be needed [20].

In our study, we evaluated a DNA methylation panel of eleven target genes responsible for self-sufficiency in growth signals (APC, ESR1, PGR B, RASSF1A, SYK and SOCS1) or for inhibition of cell invasion and metastasis formation (ADAM23, CXCL12, CDH1, TIMP3 and BRMS1). Selection of the genes was based on their previous association with advanced breast cancer [21-26]. The DNA methylation status of the selected genes was analysed by pyrosequencing, which offers a quantitative sequence-based analysis of multiple $\mathrm{CpG}$ sites and provides a comprehensive picture of the distribution of DNA methylation throughout the promoter regions of the genes studied. The aim of the study was to investigate the relationship between DNA methylation of promoter sequences and protein expression and to evaluate whether in any of the selected genes or their combinations similar DNA methylation levels could be observed simultaneously in tumours and circulating cfDNA; thus DNA methylation in plasma samples could be utilised as cancer prognostic biomarker.

\section{Patients and methods}

Patient samples. In the current study paraffin-embedded tumour tissue samples and corresponding peripheral blood cells and plasma samples from 34 newly diagnosed non-familial BC patients and 50 control blood and plasma samples were obtained from four hospitals in Bratislava and Malacky, Slovakia. This study was approved by the ethical committee and all patients and controls signed a written informed consent permitting the use of their samples for research. The associated clinico-pathological data were retrieved from the patients' clinical records and they are summarized in Table 1. At the time of $\mathrm{BC}$ diagnosis, the age of the patients ranged from 41 to 90 years. In the study group 27 (79.4\%) ductal, 4 (11.8\%) lobular and $3(8.8 \%)$ mucinous invasive breast carcinomas were included. Tumours were graded and staged according to the current WHO classification for breast neoplasms. The patients were diagnosed with stages I to IV with frequencies of 13 (38.2\%), 14 (41.2\%), 5 (14.7\%) and $2(5.9 \%)$. HER2 positivity was present in $5(14.7 \%)$ and hormone receptor negativity in $13(38.2 \%)$ patients. No neoadjuvant therapy or radiotherapy had been performed in any of the cases. The age of the controls ranged from 20 to 78 years. These persons had no signs and symptoms of cancer or other serious diseases.

DNA extraction and sodium bisulfite modification. Blood samples were obtained in EDTA-treated tubes and centrifuged at $1000 \mathrm{~g}$ for $10 \mathrm{~min}$ at room temperature within $2 \mathrm{~h}$ of venepuncture. To avoid cellular DNA contamination, supernatants were carefully collected and centrifuged again at $1000 \mathrm{~g}$ for $10 \mathrm{~min}$ at room temperature. Plasma samples 
were kept at $-70^{\circ} \mathrm{C}$ until further processing. DNA from paraffin-embedded tumour tissues was isolated by the MagneSil Genomic, Fixed Tissue System (Promega, Madison, WI), cfDNA from plasma samples was isolated using a QIAamp DSP Virus Kit (Qiagen, Hilden, Germany), and peripheral blood cell DNA was obtained using a FlexiGene DNA kit (Qiagen, Hilden, Germany) according to the manufacturer's instructions. For measurements of DNA concentration, a NanoDrop 1000 spectrophotometer (Thermo Fisher Scientific, Bremen, Germany) was used. For the DNA modification procedure we performed sodium bisulfite treatment of peripheral blood cells DNA $(1 \mu \mathrm{g})$, cfDNA $(2 \mu \mathrm{g})$ and tumour DNA $(2 \mu \mathrm{g})$ using an established protocol of the CpGenome DNA Modification Kit (Chemicon, Billerica, MA) and EpiTect Bisulfite Kit (Qiagen, Hilden, Germany), respectively. The principle of sodium bisulfite modification is based on the conversion of unmethylated cytosines to uracils in CpG dinucleotides, while 5 -methylcytosines remain unaltered. The aliquots of modified DNAs were stored at $-18^{\circ} \mathrm{C}$ until use.

Pyrosequencing methylation analysis. Quantitative DNA methylation analysis of bisulfite-treated DNA was performed by pyrosequencing in 11 genes. For each gene, we selected the $\mathrm{CpG}$ islands in the promoter area flanking the transcription start site at 5'UTR. Five to eight CpG sites were studied for each particular $\mathrm{CpG}$ island. Oligonucleotides for PCR amplification and pyrosequencing were designed using PyroMark Assay Design software 2.0 (Qiagen, Hilden, Germany) and sequences are summarized in Table 2. For genes RASSF1A and CDH1, the pyrosequencing assays, primer sequences and PCR conditions were adopted from PyroMark Assay Database (http://techsupport.pyrosequencing.com). We performed validation of all our designed pyrosequencing assays according to the manufacturer's recommendations. PCR reactions were done using the PyroMark PCR Kit (Qiagen, Hilden, Germany) according to the manual instructions, with several modifications. A total of $25 \mu \mathrm{l}$ reactions contained $2 \mu \mathrm{l}$ or $4 \mu \mathrm{l}$ sodium bisulfite-treated DNA for peripheral blood cells or cfDNA and paraffin-embedded tumour tissues, respectively. Final concentrations of the primers were $0.24 \mu \mathrm{M}$ for genes RASSF1A, $0.32 \mu \mathrm{M}$ for APC, CXCL12, ESR1, PGR B, CDH1, $S Y K, B R M S 1$ and SOCS1 genes and $0.4 \mu \mathrm{M}$ for ADAM23 and TIMP3 genes. The annealing conditions were modified for gene $A D A M 23$ to $52^{\circ} \mathrm{C}$ for $30 \mathrm{~s}$ and for TIMP3 gene to $54^{\circ} \mathrm{C}$ for $30 \mathrm{~s}$. Pyrosequencing was carried out using a PyroMark Q24 system and the PyroGold Reagent Kit (Qiagen, Hilden, Germany). The results of the analyses were evaluated using the PyroMark Q24 2.0.6. software (Qiagen, Hilden, Germany). Methylation data are presented as the percentage of average methylation in all CpG sites observed and were calculated for each sample and each gene. Analyzed samples were defined as hypermethylated if average methylation was more than 2 standard deviations from the identical gene mean value determined in peripheral blood DNA of controls. The cumulative methylation index (CMI) was calculated as
Table 1. Patients and tumour characteristics

\begin{tabular}{lc}
\hline Clinico-pathological variables $(\mathbf{N}=\mathbf{3 4})$ & $\mathrm{N}(\%)$ \\
\hline Age $($ yrs $)$ & \\
$\leq 50$ & $8(23.5)$ \\
$>50$ & $26(76.5)$ \\
Tumour histology & \\
DIC & $27(79.4)$ \\
LIC & $4(11.8)$ \\
MUC & $3(8.8)$ \\
Tumour size $(\mathbf{m m})$ & \\
$\leq 20$ & $17(50)$ \\
$>20 \leq 50$ & $14(41.2)$ \\
$>50$ & $3(8.8)$ \\
Histological grading & \\
1 & $8(23.5)$ \\
2 & $9(26.5)$ \\
3 & $15(44.1)$ \\
nd & $2(5.9)$ \\
TNM staging & \\
I. & $13(38.2)$ \\
II. & $14(41.2)$ \\
III. & $5(14.7)$ \\
IV. & $2(5.9)$ \\
ER/PR status & \\
Negative & $13(38.2)$ \\
Positive & $21(61.8)$ \\
HER2 expression & \\
Negative & $27(79.4)$ \\
Positive & $5(14.7)$ \\
nd & $2(5.9)$ \\
\hline
\end{tabular}

DIC, ductal invasive carcinomas; LIC, lobular invasive carcinomas; MUC, mucinous breast carcinomas; ER status, oestrogen receptor status; PR status, progesterone receptor status; nd, non-detected data.

ER or PR status was considered as positive in cases with $\geq 1 \%$ of positively responding cells. HER2 expression was regarded as positive, if the intensity of IHC reaction was $3+$ in $30 \%$ of tumour cells or with fluorescence in situ hybridization proven HER2 gene amplification in cases with ambiguous IHC positive at $2+$ intensity reaction.

the sum of $\% \mathrm{M}$ for all genes evaluated. For 11 genes the maximum value of methylation was CMI 1100.

Immunohistochemistry. Protein expression in malignant breast tissues was detected with specific antibodies against 11 corresponding proteins. Tissue samples were fixed in $4 \%$ formaldehyde and routinely processed in paraffin. Sections were matched to their corresponding wax blocks (the donor blocks) and $3 \mathrm{~mm}$ diameter cores of the tumour and control tissue were removed from these donor blocks with the multipurpose sampling tool Harris Uni-Core (Sigma -Aldrich, Steinheim, Germany) and inserted into the recipient master block. The recipient block was cut into $4 \mu \mathrm{m}$ thick sections and the sections were transferred to coated slides. The slides were deparaffinised, rehydrated and immersed in phosphate buffered saline buffer (10 mM, pH 7.2). Primary antibodies 
Table 2. List of PCR and pyrosequencing primers

\begin{tabular}{|c|c|c|c|c|c|c|}
\hline \multirow[b]{2}{*}{ Gene } & \multirow[b]{2}{*}{ RefSeqID } & \multirow[b]{2}{*}{ Orientation } & \multicolumn{2}{|l|}{ Amplification primers } & \multirow[t]{2}{*}{ Pyrosequencing primers } & \multirow[b]{2}{*}{$\begin{array}{l}\text { Number } \\
\text { of CpG } \\
\text { analyzed }\end{array}$} \\
\hline & & & $5^{\prime}-3^{\prime}$ Sequence & $\begin{array}{l}\text { PCR } \\
\text { product } \\
\text { size }\end{array}$ & & \\
\hline$A P C$ & NT_034772 & $\begin{array}{l}\text { Forward } \\
\text { Reverse }\end{array}$ & $\begin{array}{l}\text { GGGAAGAGGAGAGAGAAGTAGTTG } \\
\text { Biotin-AACTACACCAATACAACCACATATC }\end{array}$ & $131 b p$ & AGAGAAGTAGTTGTGTAAT & 5 \\
\hline$A D A M 23$ & NT_005403 & $\begin{array}{l}\text { Forward } \\
\text { Reverse }\end{array}$ & $\begin{array}{l}\text { Biotin-GCGTCGTTTTAGTATTTTTAGGTT } \\
\text { TCCCCAACCACTACTCССT }\end{array}$ & $89 \mathrm{bp}$ & АСТАСТСССТССССС & 8 \\
\hline$B R M S 1$ & NT_026437 & $\begin{array}{l}\text { Forward } \\
\text { Reverse }\end{array}$ & $\begin{array}{l}\text { TATTTTTTTGAGTTGGGGGTGG } \\
\text { Biotin-ACCTACAAAAAAAACCCTAATAATTCA }\end{array}$ & 125bp & TTTGAGTTGGGGGTGGG & 8 \\
\hline CXCL12 & NT_033985 & $\begin{array}{l}\text { Forward } \\
\text { Reverse }\end{array}$ & $\begin{array}{l}\text { TAGTGGGGTTTTGTTATAGGGATA } \\
\text { Biotin-ACCTTTAACCTTCTCAAACTC }\end{array}$ & $121 \mathrm{bp}$ & GGGTTTTGTTATAGGGATAAT & 7 \\
\hline ESR1A1 & NT_025741 & $\begin{array}{l}\text { Forward } \\
\text { Reverse }\end{array}$ & $\begin{array}{l}\text { GGGATGGTTTTATTGTATTAGATTTAAGG } \\
\text { Biotin-ACTTACTACTATCCAAATACACC }\end{array}$ & 115bp & GTTTTATTGTATTAGATTTAAGGG & 5 \\
\hline$P G R B$ & NT_033899 & $\begin{array}{l}\text { Forward } \\
\text { Reverse }\end{array}$ & $\begin{array}{l}\text { AGGGATTGAGAGTTTTATAGTATGT } \\
\text { Biotin-CCAAAAAAATTCTCCAACTTCTATCC }\end{array}$ & $169 \mathrm{bp}$ & GTTTGATGTTAGAGAAAAAGT & 7 \\
\hline SOCS1 & NT_010393 & $\begin{array}{l}\text { Forward } \\
\text { Reverse }\end{array}$ & $\begin{array}{l}\text { AGGGTTTAGAAGAGAGGGAAATA } \\
\text { Biotin-CCCAACTCCACTTTTAATTTCTC }\end{array}$ & $83 b p$ & GAGAGGGAAATAGGG & 7 \\
\hline$S Y K$ & NT_008470 & $\begin{array}{l}\text { Forward } \\
\text { Reverse }\end{array}$ & $\begin{array}{l}\text { GTTAAGGAAGTTGTTTAAAATGAGG } \\
\text { Biotin-TCCTCCTCGCTCTCCAAC }\end{array}$ & $83 b p$ & GAAGTTGTTTAAAATGAGGAA & 7 \\
\hline TIMP3 & NT_011520 & $\begin{array}{l}\text { Forward } \\
\text { Reverse }\end{array}$ & $\begin{array}{l}\text { GGAGGTTAAGGTTGTTT } \\
\text { Biotin-CAAACTCCAACTACCCAAAAAC }\end{array}$ & $175 b p$ & GTAAGGTAATTTTGGAGAGG & 5 \\
\hline $\mathrm{CDH} 1^{*}$ & NT_010498 & $\begin{array}{l}\text { Forward } \\
\text { Reverse }\end{array}$ & $\begin{array}{l}\text { ATTTTAGTAATTTTAGGTTAGAGGGTTA } \\
\text { Biotin-ACCACAACCAATCAACAAC }\end{array}$ & 106bp & ACCACAACCAATCAACAAC & 7 \\
\hline RASSF $1 A^{*}$ & NT_022517 & $\begin{array}{l}\text { Forward } \\
\text { Reverse }\end{array}$ & $\begin{array}{l}\text { AGTTTGGATTTTGGGGGAGG } \\
\text { Biotin-CAACTCAATAAACTCAAACTCCCC }\end{array}$ & 136bp & GGGTTAGTTTTGTGGTTT & 7 \\
\hline
\end{tabular}

${ }^{*}$ primer sequences and PCR conditions were adopted from PyroMark Assay Database

against ADAM 23 (Abcam, Cambridge, UK) BRMS1 (Abcam, Cambridge, UK), SOCS1 (Abcam, Cambridge, UK), Syk (Abcam, Cambridge, UK), TIMP3 (Abcam, Cambridge, UK), APC (Abcam, Cambridge, UK), RASSF1 (Abcam, Cambridge, UK), Cdh1 Ab-1 (Thermo Scientific, Fremont, USA), CXCL 12 (Life Span BioSciencies), oestrogen and progesterone receptors (Dako, Glostrup, Denmark) were used for tumour staining. The slides were incubated with the primary antibody according to the manufacturer's instructions. For visualisation, we used the EnVision system with horseradish peroxidase and diaminobenzidine chromogen solution (DAB, Dako, Glostrup, Denmark). The slides were counterstained with haematoxylin. As positive control, we used normal tissue that was included on the tissue microarrays. As negative control, breast tissue was used, omitting the primary antibody from the staining protocol. The result of the immunohistochemical analyses was expressed by an ImmunoReactive Score (IRS), so-called German IRS, evaluating both the percentage of positive cells (PP) and the staining intensity (SI) of the nuclei or cytoplasm [27]. Shortly, SI was subdivided into four categories $(0=$ negative, $1=$ weakly positive, $2=$ moderately positive, $3=$ strongly positive). PP was graded as follows: $0=$ negative, $1=$ up to 10 percentage positive cells, $2=$ from 11 to 50 percentage positive cells, $3=$ from 51 to 80 percentage positive cells, and $4=$ more than 80 percentage positive cells. SI and PP were then combined by multiplication giving four IRS categories: negative, weak, moderate and high protein expression.

Statistical analysis. Statistical software SPSS statistics 15.0 was used for statistical analyses of the data. Normality of distribution was tested by the Kolmogorov-Smirnoff test. If normally distributed, sample means were tested by Student $\mathrm{t}$-test or analysis of variance (ANOVA) with Bonferroni's or Tamhane's corrections depending on homogeneity of variance. Nonparametric Mann-Whitney $U$ or Kruskal-Wallis H test were used for non-normally distributed data. Pearson's or Spearman's correlations were used according to the normality of data. All tests were two-tailed performed at the significance level $P<0.05$. Categorical data were tested by Chi square. Adjustment for age was performed using analysis of covariance (ANCOVA).

\section{Results}

Bisulfite pyrosequencing was used to investigate DNA methylation profiles in formalin fixed paraffin-embedded tumour tissues, plasma samples and blood cells. The results of DNA methylation levels in 11genes were compared in $34 \mathrm{BC}$ patients and 50 healthy controls. We observed hypermethyla- 
tion of four evaluated genes in tumours. The most commonly hypermethylated gene was RASSF $1 A$ in $71.9 \%$ of patients with methylation level up to $86 \%$. APC, ADAM23 and CXCL12 genes were hypermethylated in $55.9 \%, 38 \%$ and $34.4 \%$ of cases with respective maximal methylation values of 86,53 and $64 \%$. DNA methylation levels were significantly higher in peripheral blood cells of patients compared to controls in CXCL12, ESR1 and TIMP3 genes (Table 3), although levels of DNA methylation did not exceed $15 \%$ in any of the genes studied. Moreover, significant differences between methylation levels in tumours and peripheral blood cell DNA of patients were observed in APC, ADAM23, CXCL12, ESR1, CDH1, RASSF1A, SYK, BRMS1 and SOCS1 genes.

None or only mild DNA methylation levels up to $23 \%$ were found in most of patients' plasma samples, however in rare cases DNA methylation levels $47,44,30$ and $50 \%$ in respective APC, ADAM23, SYK and TIMP3 genes were manifested. Though there were no significant differences between DNA methylation in plasma samples between cases and controls, with exception of $C D H 1$ gene $(P=0.045)$, this result is nevertheless controversial for the higher mean in control plasma and higher maximal methylation level in patient plasma (Table 4). DNA methylation in plasma samples of BC patients was significantly lower than in tumour samples for the majority of the genes studied, with exception of CDH1, TIMP3 and BRMS1; there were thus no correlations between DNA methylation in tumours and plasma samples from patients in any of the genes studied (Fig. 1).

The CMI means in tumour tissues and plasma samples were $137.5 \pm 60.3$ and $43.6 \pm 20.1$, respectively, compared with CMI mean $39.1 \pm 8.1$ in patients' peripheral blood cell DNA. In patients, the cumulative DNA methylation in tumours was significantly higher than in plasma samples $(P<$ 0.001). Comparison of CMIs in patients' tumour and cfDNA are presented in Fig. 2. On the other hand, the CMI mean in the healthy control group of women was $43.7 \pm 15.0$ and 33.2

Table 3. Comparison of DNA methylation (in \%) between breast cancer patients and controls in peripheral blood cells

\begin{tabular}{|c|c|c|c|c|c|}
\hline \multirow[t]{2}{*}{ Genes } & \multicolumn{2}{|c|}{$\begin{array}{c}\text { Controls } \\
\mathrm{N}=50\end{array}$} & \multicolumn{2}{|c|}{$\begin{array}{c}\text { Patients } \\
\mathrm{N}=34\end{array}$} & \multirow[t]{2}{*}{$P$ value ${ }^{*}$} \\
\hline & Mean \pm SD & Range & Mean \pm SD & Range & \\
\hline$A P C$ & $1.28 \pm 0.57$ & $(1-4)$ & $1.68 \pm 1.04$ & $(1-6)$ & 0.082 \\
\hline$A D A M 23$ & $2.18 \pm 0.39$ & $(2-3)$ & $2.29 \pm 0.58$ & $(1-3)$ & 0.511 \\
\hline CXCL12 & $2.28 \pm 0.50$ & $(1-3)$ & $2.79 \pm 0.84$ & $(2-5)$ & 0.044 \\
\hline ESR1 & $3.22 \pm 0.86$ & $(2-6)$ & $4.09 \pm 1.44$ & $(2-9)$ & 0.026 \\
\hline$P G R B$ & $4.32 \pm 1.13$ & $(1-7)$ & $5.41 \pm 2.03$ & $(3-13)$ & 0.056 \\
\hline $\mathrm{CDH} 1$ & $9.02 \pm 1.60$ & $(4-12)$ & $9.64 \pm 2.10$ & $(4-15)$ & 0.698 \\
\hline RASSF1A & $1.04 \pm 0.28$ & $(0-2)$ & $1.00 \pm 0.00$ & $(1-1)$ & 0.475 \\
\hline SYK & $1.06 \pm 0.24$ & $(1-2)$ & $1.15 \pm 0.44$ & $(1-3)$ & 0.638 \\
\hline TIMP3 & $2.50 \pm 0.81$ & $(1-5)$ & $3.65 \pm 2.55$ & $(1-14)$ & 0.036 \\
\hline BRMS1 & $1.40 \pm 0.70$ & $(1-3)$ & $1.56 \pm 0.93$ & $(1-6)$ & 0.726 \\
\hline SOCS1 & $0.96 \pm 0.28$ & $(0-2)$ & $1.09 \pm 0.38$ & $(1-3)$ & 0.271 \\
\hline
\end{tabular}

${ }^{\star} P$ value for the difference between controls and patients adjusted for age by the analysis of covariance (ANCOVA).

Table 4. Comparison of DNA methylation (in \%) between breast cancer patients and controls in plasma samples

\begin{tabular}{|c|c|c|c|c|c|}
\hline \multirow[t]{2}{*}{ Genes } & \multicolumn{2}{|c|}{$\begin{array}{c}\text { Controls } \\
\mathrm{N}=50\end{array}$} & \multicolumn{2}{|c|}{$\begin{array}{c}\text { Patients } \\
\mathrm{N}=34\end{array}$} & \multirow[t]{2}{*}{$P$ value ${ }^{*}$} \\
\hline & Mean \pm SD & Range & Mean \pm SD & Range & \\
\hline$A P C$ & $2.53 \pm 1.56$ & $(0-6)$ & $4.41 \pm 7.81$ & $(1-47)$ & 0.060 \\
\hline$A D A M 23$ & $2.69 \pm 1.50$ & $(1-9)$ & $3.82 \pm 7.33$ & $(1-44)$ & 0.073 \\
\hline CXCL12 & $2.68 \pm 1.92$ & $(1-11)$ & $2.85 \pm 2.84$ & $(1-15)$ & 0.879 \\
\hline ESR1 & $5.24 \pm 4.33$ & $(1-23)$ & $4.18 \pm 4.07$ & $(1-18)$ & 0.338 \\
\hline$P G R B$ & $4.69 \pm 5.85$ & $(1-32)$ & $2.97 \pm 2.15$ & $(1-8)$ & 0.206 \\
\hline $\mathrm{CDH} 1$ & $7.73 \pm 3.60$ & $(1-15)$ & $6.53 \pm 5.32$ & $(1-23)$ & 0.045 \\
\hline RASSF1A & $4.02 \pm 6.62$ & $(1-36)$ & $2.85 \pm 3.13$ & $(1-18)$ & 0.404 \\
\hline$S Y K$ & $2.14 \pm 2.28$ & $(0-12)$ & $3.00 \pm 5.65$ & $(0-31)$ & 0.488 \\
\hline TIMP3 & $3.92 \pm 4.54$ & $(0-31)$ & $3.97 \pm 8.43$ & $(0-50)$ & 0.697 \\
\hline$B R M S 1$ & $2.56 \pm 1.57$ & $(0-8)$ & $3.12 \pm 2.36$ & $(0-10)$ & 0.516 \\
\hline SOCS1 & $2.08 \pm 1.91$ & $(1-11)$ & $1.76 \pm 0.90$ & $(1-4)$ & 0.358 \\
\hline
\end{tabular}

${ }^{*} P$ value for the difference between controls and patients adjusted for age by the analysis of covariance (ANCOVA). 


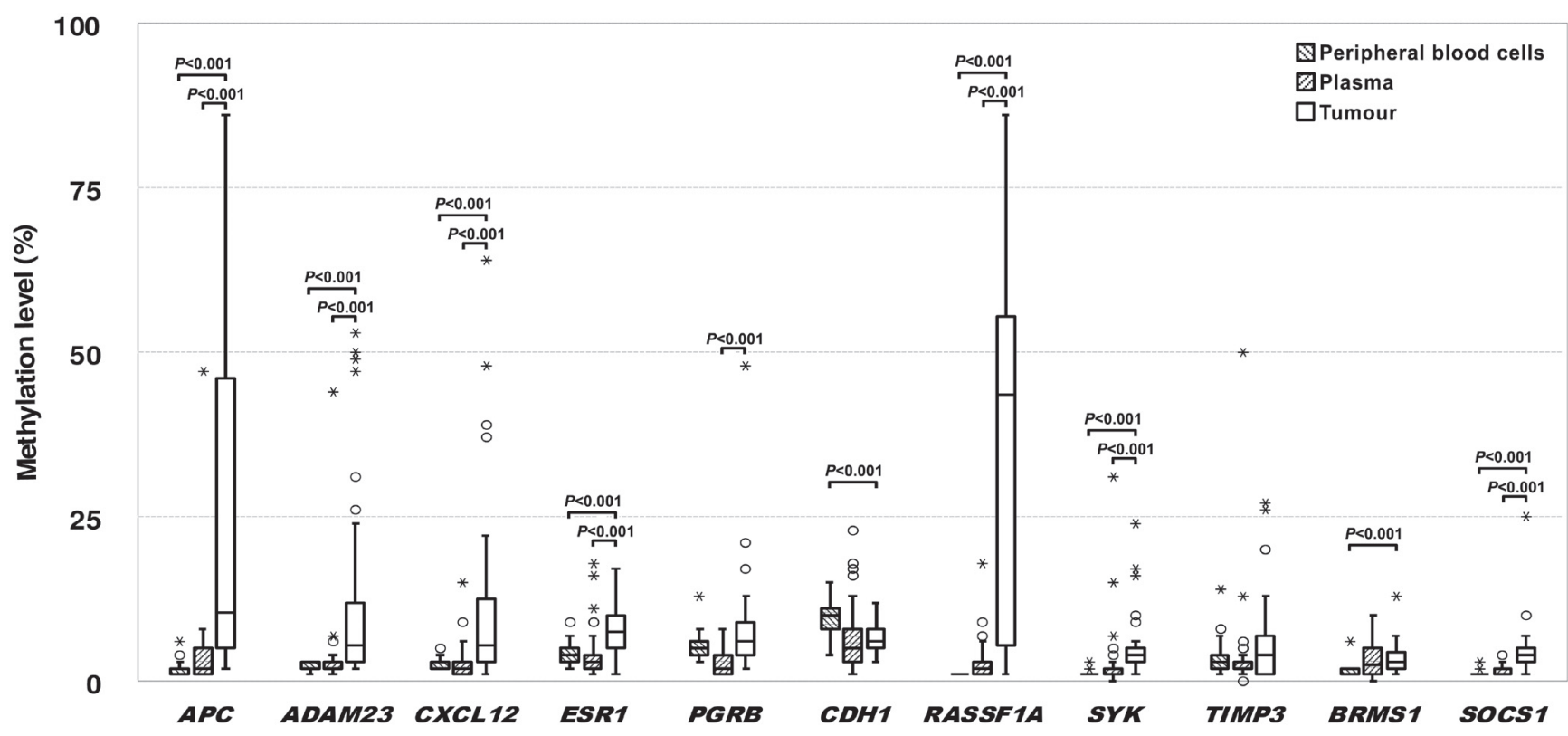

Figure 1. DNA methylation levels (\%) for 11 analysed genes in peripheral blood cells, plasma and paraffin-embedded tumour samples of breast cancer patients

$P$ values represent differences between peripheral blood cells and tumour samples or between plasma and tumour samples. The length of the boxes is the interquartile range (IQR) that represents values between the 75th and 25th percentiles. Values more than three IQR's from the end of a box are labelled as extreme $\left(^{*}\right)$. Values more than 1.5 IQR's but less than 3 IQR's from the end of the box are labelled as outliers $(\mathrm{O})$. The median is depicted by horizontal line.

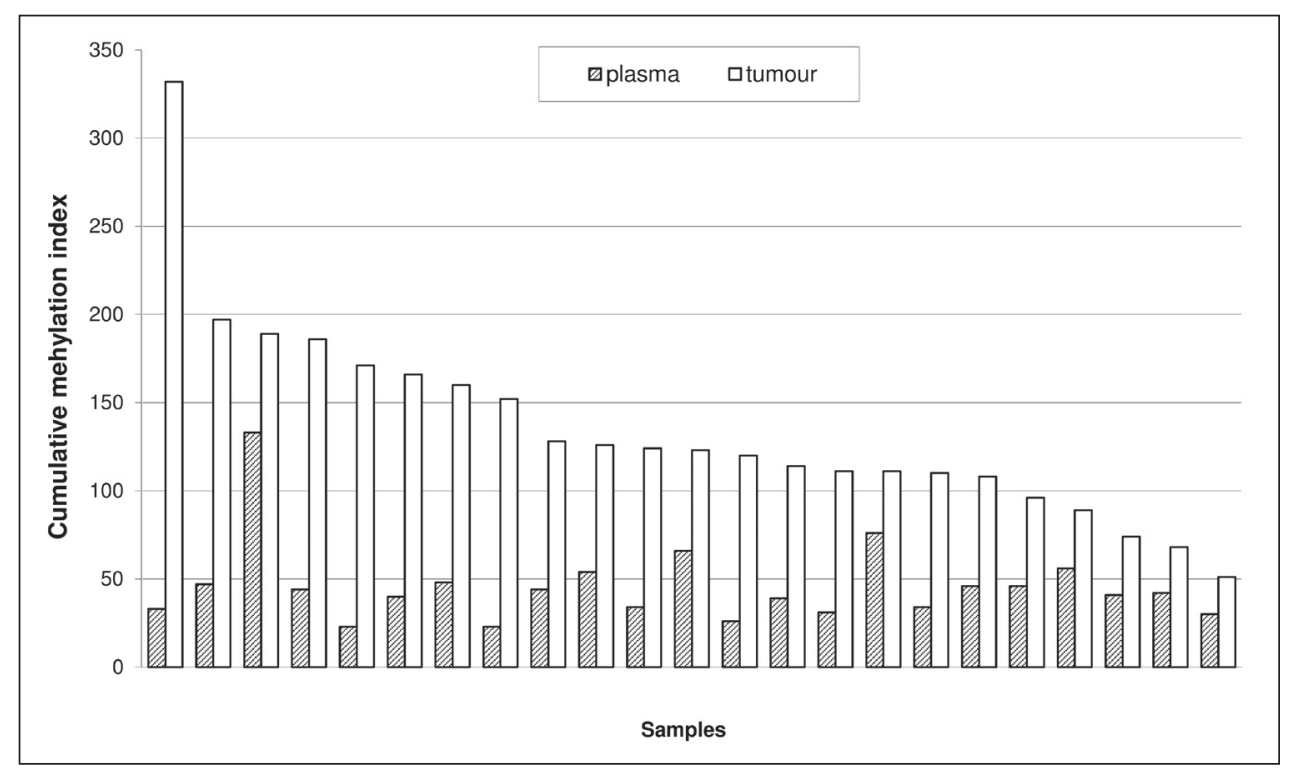

Figure 2. Cumulative methylation index for paraffin-embedded tumour and plasma samples in breast cancer patients Cumulative methylation index is the sum of $\% \mathrm{M}$ for eleven evaluated genes.

\pm 4.1 in plasma and peripheral blood cell DNA, respectively. The value of cumulative methylation in peripheral blood cell DNA of patients and controls was significantly different (39.1 \pm 8.1 vs. $33.2 \pm 4.1 ; \mathrm{P}<0.006)$, in contrast to nearly identical cumulative methylation in plasma DNA of patients and controls $(43.6 \pm 20.1$ vs. $43.7 \pm 15.0)$.

Immunohistochemical staining was used to determine relevant protein expression. Variable expression profiles were 

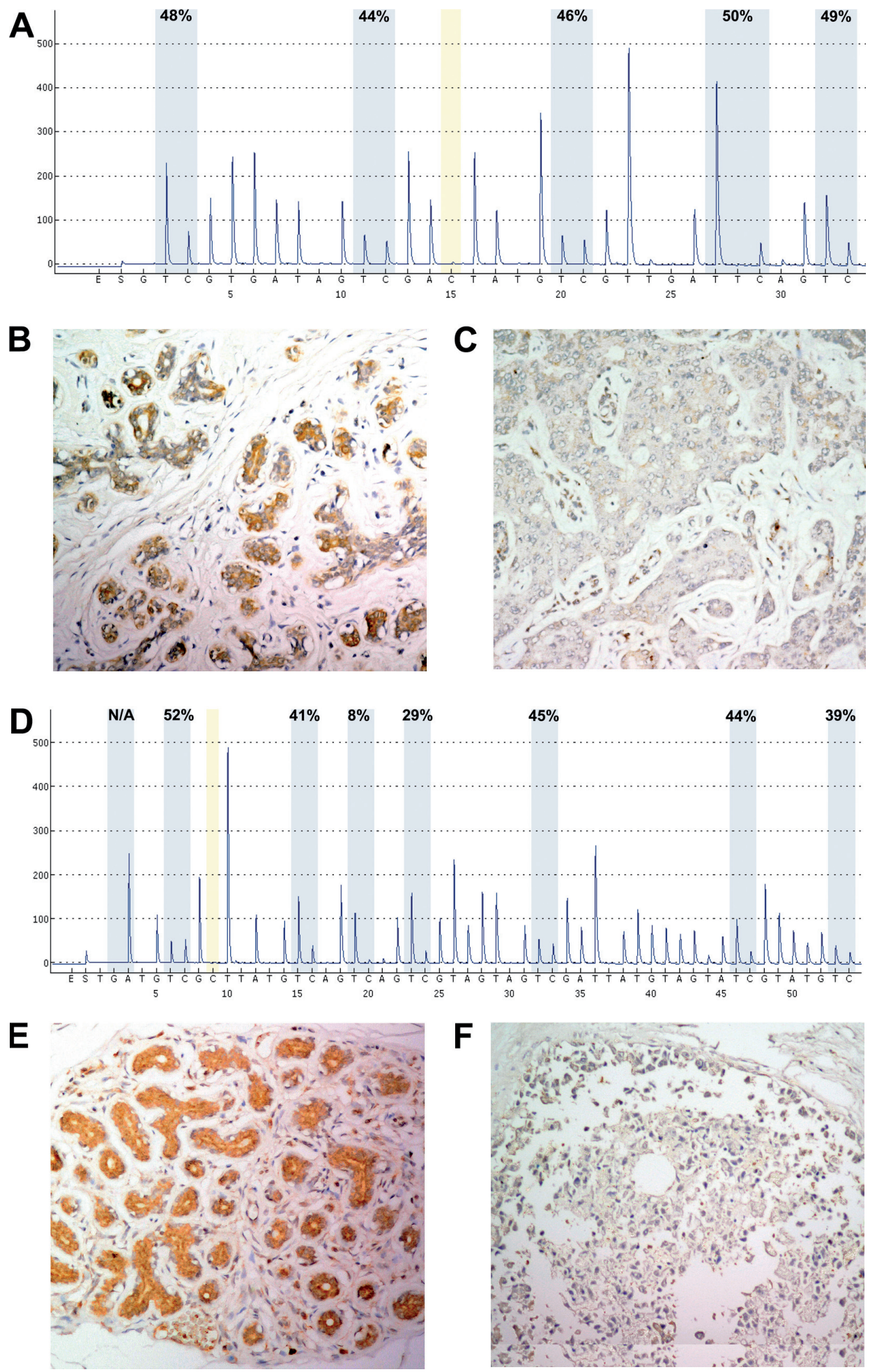

Figure 3. Association between promoter methylation and inhibition of relevant protein expression

A: Pyrosequencing result of the $A P C$ gene promoter region with average DNA methylation in the tumour of $47 \%$

B: Normal breast tissue. Immunohistochemical staining with antibody against APC Magnification $350 \mathrm{x}$

C: Breast carcinoma. Immunohistochemical staining with antibody against APC Magnification $350 \mathrm{x}$

D: Pyrosequencing result of the CXCL12 gene promoter region with average DNA methylation in the tumour of $39 \%$

E: Normal breast tissue. Immunohistochemical staining with antibody against CXCL 12 Magnification $350 \mathrm{x}$

F: Breast carcinoma. Immunohistochemical staining with antibody against CXCL 12 Magnification $350 \mathrm{x}$ 
identified for the proteins analysed, ranging from negative to high expression. The highest frequency of negative protein expression was found for TIMP3 protein (70\%) and positive protein expression for ESR1 (60.6\%). In the highly methylated $A P C$ gene a visible decreasing trend of mean methylation levels from $68 \%$ to $19 \%$ was observed in association with an increasing protein expression. Similar results were found in CXCL12, where the mean methylation level $24.17 \%$ was reduced to $4.33 \%$; however in both genes without significant difference. The examples of pyrosequencing results in patients with average methylation level 47\% in APC and 39\% in CXCL12 gene and with low protein expressions in both proteins are presented in Figure 3.

\section{Discussion}

DNA methylation analysis in promoters of 11 genes, namely, APC, ADAM23, CXCL12, ESR1, PGR B, CDH1, RASSF1A, SYK, TIMP3, BRMS1 and SOCS1, as well as immunohistochemical analysis of related proteins in paraffin-embedded tumour tissues were realised with the purpose to investigate the relationship between DNA methylation and protein expression and to find a useful plasma-based marker for BC. In our study, tumour samples showed a wide range of promoter DNA methylation as well as protein expression. The most frequent methylation was found in RASSF1A gene promoter that was hypermethylated in $71.9 \%$ of the $\mathrm{BC}$ patients assessed, with the mean level 50.3\%. Comparable results were described for BC cases in our previous study, i.e.82.1\% methylation frequency with the mean level $48.45 \%$ in RASSF1A gene using QMMSP [28]. Other authors showed similar frequencies of $68 \%$ and $82.5 \%$ or notably lower means of RASSF1A methylation levels, i.e. $18.5 \pm 4.7 \%[6,29]$. The important role of RASSF1A epigenetic silencing in $\mathrm{BC}$ was presented by very high methylation levels in RASSF1A gene in many studies regardless ethnicity of the population studied $[6,30]$. In another study, the association of RASSF1A methylation with time to first recurrence and overall survival was observed. These data suggest that RASSF1A methylation could be a potential prognostic biomarker [31]. Costa and co-workers showed higher methylation frequency of $A D A M 23$ promoter in primary tumours of BC patients compared to our results (69.2\% vs. $38.2 \%)$ [25]. Other authors reported in BC different CXCL12 methylation frequencies, i.e. $14.5 \%$ and $52.4 \%[23,32]$, compared to our study where the frequency was $34.4 \%$. Patients with CXCL12 methylation had a shorter overall survival and disease-free survival. These findings suggest that the DNA methylation status of CXCL12 gene could be used as a prognostic biomarker in $\mathrm{BC}[33,34]$. Our results showed that APC belonged also to the most frequently methylated genes. The frequency of hypermethylation was $55.9 \%$, with the mean level $40.3 \%$. Other studies reported lower or similar frequencies of APC gene methylation, ranging from 28 to $53 \%[35,36]$, which correlated with reduced APC protein levels [37]. In our study, the results of quantification of $A P C$ gene methylation with immunohisto- chemical evaluation of protein expression indicate that DNA methylation of $A P C$ gene could initiate inhibition of relevant protein expression. We also observed a decreasing trend of methylation levels in association with increasing protein expression for CXCL12 gene. A strong relationship between CXCL12 methylation and protein expression was verified by other authors [32,38]. Moreover, a low CXCL 12 protein level was associated with poor prognosis [33, 39]. In other genes studied, we did not find a clear association between DNA methylation levels and relevant protein expressions, evaluated by the semi-quantitative IRS method. Our results suggest that the DNA methylation profiles observed in our group of breast carcinomas are not the only cause that affects the silencing of the genes evaluated and the decrease of relevant protein products. Other mechanisms regulating gene expression may be involved, such as post-transcriptional modifications of histones and chromatin rearrangement, as well as aberrant miRNA regulation. All of these modifications participate in compression or relaxation processes of chromatin structures that contribute to gene expression regulation [40]. In a recently published review, Hervouet and co-authors provided strong evidence that expression of oestrogen target genes was tightly regulated by multiple and highly dynamic mechanisms using classical co-recruitment of oestrogen receptors and co-activators/co-repressors or by epigenetic manner, including receptor complexes with histone acetyltransferases, histone deacetylases, histone methyltransferases, DNA methyltransferases and Polycomb proteins [41]. Another example of the complexity of gene expression regulation was presented in a cell line study where the regulation of RASSF1A gene was affected by simultaneous DNA and protein methylation. The investigators demonstrated that simultaneous targeting of DNA and E2F1 transcription factor methylation was an effective epigenetic treatment reactivating RASSF $1 A$ expression and inducing apoptosis in breast cancer cells [42]. Other authors showed the influence of miRNAs on epigenetic switches in DNA methylation and histone modification of RASSF1A gene in $\mathrm{BC}$ [20]. The above mentioned results indicate that in addition to epigenetic silencing of gene expression through DNA methylation of promoter sequences there are other mechanisms that affect gene and the following protein expression. Thus we did not observe a clear association between DNA methylation and relevant protein expression, despite the findings of a wide range of promoter DNA methylation levels and/or variable protein expression in the samples evaluated.

To determine whether DNA methylation patterns identified in tumours can be found in peripheral blood, we analysed DNA methylation levels of cfDNA and peripheral blood cells DNA of BC patients and controls. Peripheral blood is a very attractive medium for the development of molecular biomarkers for cancer detection, prognostic assessment and treatment response assays as it is obtained through a simple, relatively non-invasive procedure. A list of studies reported aberrant plasma/serum DNA methylation of a single gene or a panel of genes in $\mathrm{BC}$ patients, using different quantitative or 
qualitative assays [11-15]. Variations in results from different studies could be attributed to differences in clinical status and methodological approaches used for analysis. The widely used semi-quantitative methods, such as MSP, bear a significant risk of false-positive or false-negative results, especially when the DNA quality and/or quantity is low, which is often the case in clinical settings. In comparison to the other quantitative methods as COBRA (combined bisulfite restriction analysis), SIRPH (SNuPE ion pair-reverse phase high-performance liquid chromatography) or Q-MSP (quantitative methylation specific PCR), pyrosequencing has been shown to be the most reliable method that fulfils also the basic requirements of clinical settings, such as robustness, cost efficiency and easy use $[43,44]$. As a general observation from DNA methylation studies, the RASSF1A gene appeared to be a promising biomarker of BC in plasma/serum. However, several authors questioned the serious clinical utility of circulating DNA as a biomarker of cancer for moderate concordance in terms of the presence of methylation of genes between tumour tissues and plasma/serum of cancer patients and overall relatively low methylation frequencies in serum compared to matched tumour samples [reviewed in 45,46 ]. Similarly to our results, modest differences of cfDNA methylation between $\mathrm{BC}$ cases and controls were reported [16, 47]. Korshunova and colleagues found a high background of overall methylation in serum of cancer-free individuals and nearly identical DNA methylation levels in four $\mathrm{BC}$ associated genomic regions for $\mathrm{BC}$ cases and controls [48]. Massively parallel bisulphite pyrosequencing revealed the complex nature of the cytosinemethylation landscape of both serum and tissue DNA and no special type of methylation pattern was found in a statistically meaningful way exclusively in cancerous or normal tissues, including serum [47]. Circulating tumour cells as a source of cancer-related DNA methylation were reported by Matuschek and colleagues. They observed a correlation between DNA methylation in APC and GSTP1 genes in serum with the presence of circulating blood tumour cells, which are associated with a more aggressive and advanced BC disease [49]. Our current results are in concordance with our previous study where we found different spectra of methylated genes in plasma compared to tumour samples, using the RT-based quantitative method [28]. Estimations of the concentration of tumour-derived DNA in serum, based on detection of tumour-specific mutations, demonstrated that the amount of this DNA was less than 0.2\% [50]. As discussed in Korshunova and co-authors, the expected methylation signals from such minute amounts are so close to the background level that robust detection of tumour-shed DNA would seem to be problematic, especially in the case of an epigenetically complex background [47]. For this reason, the use of PCRbased methods that are able to detect no less than a twofold difference will remain challenging. This could be the main obstacle in finding tumour specific differences in sera/plasma and the main reason of the lack of sensitivity of the epigenetic biomarkers studied [45]. The implication of these findings for further blood-based epigenetic research is the need for identification of markers with the largest possible epigenetic differences between diseased and normal serum.

Recently, several articles were published discussing the role of aberrant global and gene specific DNA methylation in peripheral blood cells in breast and other cancers [reviewed in 51,20$]$. The results showed that some systemic epigenetic changes would be detected in peripheral blood DNA in breast, pancreatic, bladder and colorectal cancers [18, 52-55]. In our study, significantly higher levels of promoter DNA methylation of three genes were found in peripheral blood cells of $\mathrm{BC}$ patients compared to controls. It has been suggested that cancer specific genetic variants or immunologic processes related to inflammation in cancer development may lead to methylation changes in leukocyte subpopulations that are manifested in peripheral blood [56,57]. Greater insight into the origin and nature of DNA methylation changes in peripheral blood as well as information about DNA methylation pattern in heterogeneous leukocyte subpopulations are needed to determine if DNA methylation in peripheral blood cells could serve as an informative biomarker in cancer diagnosis and treatment [20].

\section{Conclusions}

Despite the finding of no clear association between DNA methylation and protein expression, we can conclude that the quantitative analyses of tumour DNA methylation in any of RASSF1A, ADAM23, CXCL12 and APC genes could have prognostic potential. DNA methylation in plasma samples of $\mathrm{BC}$ patients is currently not suitable for translation into clinical use due to the technological challenges and insufficient knowledge of origin and nature of cfDNA methylation. However, the significantly higher level of promoter DNA methylation in peripheral blood cells of BC patients compared to controls in our study support the idea that the analyses of DNA methylation in peripheral leukocytes of cancer patients could have a potential to become an informative biomarker of cancer risk and prognosis.

Acknowledgments: We thank Zuzana Cierna, Jana Mlynarcikova and Matej Bohmer for sample collection management and also Gabriela Gasajova, Denisa Manasova, Emilia Klincova and Lucia Donarova for excellent technical assistance. This publication is the result of the implementation of projects: no. APVV-0076-10 supported by the Slovak Research and Development Agency (40\%), no. 26240220058, Research and Development Operational Programme funded by the ERDF (50\%) and 2/0120/13 funded by the Slovak Grant Agency VEGA (10\%).

\section{References}

[1] TRAPE AP, GONZALEZ-ANGULO AM Breast cancer and metastasis: on the way toward individualized therapy. Cancer Genomics Proteomics 2012; 9(5): 297-310 
[2] ESTELLER M Cancer epigenomics: DNA methylomes and histone-modification maps. Nat Rev Genet 2007; 8(4): 286-298. http://dx.doi.org/10.1038/nrg2005

[3] LEWIS CM, CLER LR, BU DW, ZOCHBAUER-MULLER S, MILCHGRUB S et al. Promoter hypermethylation in benign breast epithelium in relation to predicted breast cancer risk. Clin Cancer Res 2005; 11(1): 166-172.

[4] ESTELLER M, CORN PG, BAYLIN SB, HERMAN JG A gene hypermethylation profile of human cancer. Cancer Res 2001; 61: 3225-3229.

[5] PASQUALI L, BEDEIR A, RINGQUIST S, STYCHE A, BHARGAVA R et al. Quantification of CpG island methylation in progressive breast lesions from normal to invasive carcinoma. Cancer Lett 2007; 257(1): 136-144. http://dx.doi.org/10.1016/ j.canlet.2007.07.010

[6] FACKLER MJ, MC VEIGH M, MEHROTRA J, BLUM MA, LANGE J et al. Quantitative multiplex methylation-specific PCR assay for the detection of promoter hypermethylation in multiple genes in breast cancer. Cancer Res 2004; 64(13): 4442-4452. http://dx.doi.org/10.1158/0008-5472.CAN-03$\underline{3341}$

[7] ZOCHBAUER-MULLER S, FONG KM, MAITRA A, LAM S, GERADTS J et al. 5' CpG island methylation of the FHIT gene is correlated with loss of gene expression in lung and breast cancer. Cancer Res 2001; 61(9): 3581-5.

[8] MAO XY, CHEN H, WANG H, WEI J, LIU C et al. MTA1 expression correlates significantly with ER-alpha methylation in breast cancer. Tumour Biol 2012; 33(5): 1565-1572. http://dx.doi.org/10.1007/s13277-012-0410-7

[9] ZHAO Y, ZHOU H, MA K, SUN J, FENG X et al. Abnormal methylation of seven genes and their associations with clinical characteristics in early stage non-small cell lung cancer. Oncol Lett 2013; 5(4): 1211-1218.

[10] DEHAN P, CANON C, TROOSKENS G, REHLI M, MUNAUT C et al. Expression of type 2 orexin receptor in human endometrium and its epigenetic silencing in endometrial cancer. J Clin Endocrinol Metab 2013; 98(4): 1549-1557. http://dx.doi.org/10.1210/jc.2012-3263

[11] HU XC, WONG IH, CHOW LW Tumor-derived aberrant methylation in plasma of invasive ductal breast cancer patients: clinical implications. Oncol Rep 2003; 10(6): 1811-1815.

[12] MULLER HM, WIDSCHWENDTER A, FIEGL H, IVARSSON L, GOEBEL G et al. DNA methylation in serum of breast cancer patients: an independent prognostic marker. Cancer Res 2003; 63(22): 7641-7645.

[13] DULAIMI E, HILLINCK J, IBANEZ DE CACERES I, ALSALEEM T, CAIRNS P Tumor suppressor gene promoter hypermethylation in serum of breast cancer patients. Clin Cancer Res 2004; 10(18 Pt 1): 6189-6193. http://dx.doi. org/10.1158/1078-0432.CCR-04-0597

[14] FIEGL H, MILLINGER S, MUELLER-HOLZNER E, MARTH C, ENSINGER C et al. Circulating tumor-specific DNA: a marker for monitoring efficacy of adjuvant therapy in cancer patients. Cancer Res 2005; 65(4): 1141-1145. http://dx.doi. org/10.1158/0008-5472.CAN-04-2438

[15] HOQUE MO, FENG Q, TOURE P, DEM A, CRITCHLOW $\mathrm{CW}$ et al. Detection of aberrant methylation of four genes in plasma DNA for the detection of breast cancer. J Clin Oncol 2006; 24(26): 4262-4269. http://dx.doi.org/10.1200/ LCO.2005.01.3516

[16] STURGEON SR, BALASUBRAMANIAN R, SCHAIRER C, MUSS HB, ZIEGLER RG et al. Detection of promoter methylation of tumor suppressor genes in serum DNA of breast cancer cases and benign breast disease controls. Epigenetics 2012; 7(11): 1258-1267. http://dx.doi.org/10.4161/epi.22220

[17] MIKESKA T, BOCK C, DO H, DOBROVIC A DNA methylation biomarkers in cancer: progress towards clinical implementation. Expert Rev Mol Diagn 2012; 12(5): 473-487. http://dx.doi.org/10.1586/erm.12.45

[18] FLANAGAN JM, MUNOZ-ALEGRE M, HENDERSON S, TANG T, SUN P et al. Gene-body hypermethylation of ATM in peripheral blood DNA of bilateral breast cancer patients. Hum Mol Genet 2009; 18(7): 1332-1342. http://dx.doi. org/10.1093/hmg/ddp033

[19] WIDSCHWENDTER M, MENON U Circulating methylated DNA: a new generation of tumor markers. Clin Cancer Res 2006; 12(24): 7205-7208. http://dx.doi.org/10.1158/10780432.CCR-06-2531

[20] LI L, CHOI JY, SUNG H, PARK SK, OZE I DNA methylation in peripheral blood: a potential biomarker for cancer molecular epidemiology. J Epidemiol 2012; 22(5): 384-394. http://dx.doi. org/10.2188/jea.JE20120003

[21] CHO YH, SHEN J, GAMMON MD, ZHANG YJ, WANG Q et al. Prognostic significance of gene-specific promoter hypermethylation in breast cancer patients. Breast Cancer Res Treat 2012; 131(1): 197-205. http://dx.doi.org/10.1007/s10549-011$\underline{1712-y}$

[22] GAUDET MM, CAMPAN M, FIGUEROA JD, YANG XR, LISSOWSKA J et al. DNA hypermethylation of ESR1 and PGR in breast cancer: pathologic and epidemiologic associations. Cancer Epidemiol Biomarkers Prev 2009; 18(11): 3036-3043. http://dx.doi.org/10.1158/1055-9965.EPI-09-0678

[23] RAMOS EA, CAMARGO AA, BRAUN K, SLOWIK R, CAVALLI IJ et al. Simultaneous CXCL12 and ESR1 CpG island hypermethylation correlates with poor prognosis in sporadic breast cancer. BMC Cancer 2010; 10:23. http://dx.doi. org/10.1186/1471-2407-10-23

[24] YUAN Y, MENDEZ R, SAHIN A, DAI JL Hypermethylation leads to silencing of the SYK gene in human breast cancer. Cancer Res 2001; 61(14): 5558-5561.

[25] COSTA FF, VERBISCK NV SALIM AC, IERARDI DF, PIRES LC et al. Epigenetic silencing of the adhesion molecule ADAM23 is highly frequent in breast tumors. Oncogene 2004; 23: 1481-1488. http://dx.doi.org/10.1038/sj.onc.1207263

[26] METGE BJ, FROST AR, KING JA, DYESS DL, WELCH DR et al. Epigenetic silencing contributes to the loss of BRMS1 expression in breast cancer. Clin Exp Metastasis 2008; 25(7): 753-63. http://dx.doi.org/10.1007/s10585-008-9187-x

[27] REMMELE W, SCHICKETANZ KM Immunohistochemical determination of estrogen and progesterone receptor content in human breast cancer. Computer-assisted image analysis (QIC score) vs. subjective grading (IRS). Pathol Res Pract 1993; 189(8): 862-866. http://dx.doi.org/10.1016/S03440338(11)81095-2 
[28] KAJABOVA V, SMOLKOVA B, ZMETAKOVA I, SEBOVA K, KRIVULCIK T et al. RASSF1A promoter methylation levels positively correlate with oestrogen receptor expression in breast cancer patients. Trans Onc 2013; 6(3): 297-304.

[29] CHO YH, YAZICI H, WU HC, TERRY MB, GONZALES $\mathrm{K}$ et al. Aberrant promoter hypermethylation and genomic hypomethylation in tumor, adjacent normal tissues and blood from breast cancer patients. Anticancer Res 2010; 30: 2489-2496.

[30] BUHMEIDA A, MERDAD A, AL-MAGHRABI J, ALTHOBAITI F, ATA $M$ et al. RASSF1A methylation is predictive of poor prognosis in female breast cancer in a background of overall low methylation frequency. Anticancer Res 2011; 31: 2975-2981.

[31] XU J, SHETTY PB, FENG W, CHENAULT C, BAST RC JR at al. Methylation of HIN-1, RASSF1A, RIL and CDH13 in breast cancer is associated with clinical characteristics, but only RASSF1A methylation is associated with outcome. BMC Cancer 2012; 12: 243. http://dx.doi.org/10.1186/1471-2407-12-243

[32] ZHOU W, JIANG Z, LIU N, XU F, WEN P et al. Downregulation of CXCL12 mRNA expression by promoter hypermethylation and its association with metastatic progression in human breast carcinomas. J Cancer Res Clin Oncol 2009; 135(1): 91-102. http://dx.doi.org/10.1007/s00432-0080435-X

[33] MIRISOLA V, ZUCCARINO A, BACHMEIER BE, SORMANI MP, FALTER J et al. CXCL12/SDF1 expression by breast cancers is an independent prognostic marker of disease-free and overall survival. Eur J Cancer 2009; 45(14): 2579-2587. http://dx.doi.org/10.1016/j.ejca.2009.06.026

[34] RAMOS EA, GROCHOSKI M, BRAUN-PRADO K, SENISKI GG, CAVALLI IJ et al. Epigenetic changes of CXCR4 and its ligand CXCL12 as prognostic factors for sporadic breast cancer. PLoS One 2011; 6(12): e29461. http://dx.doi. org/10.1371/journal.pone.0029461

[35] JIN Z, TAMURA G, TSUCHIYA T, SAKATA K, KASHIWABA $\mathrm{M}$ et al. Adenomatous polyposis coli (APC) gene promoter hypermethylation in primary breast cancers. Br J Cancer 2001; 85: 69-73. http://dx.doi.org/10.1054/bjoc. 2001.1853

[36] VIRMANI AK, RATHI A, SATHYANARAYANA UG, PADAR A, HUANG CX et al. Aberrant methylation of the adenomatous polyposis coli (APC) gene promoter $1 \mathrm{~A}$ in breast and lung carcinomas. Clin Cancer Res 2001; 7: 1998-2004.

[37] LIU Z, YANG L, CUI DX, LIU BL, ZHANG XB et al. Methylation status and protein expression of adenomatous polyposis coli (APC) gene in breast cancer. Ai Zheng 2007; 26: 586-590.

[38] WENDT MK, COOPER AN, DWINELL MB. Epigenetic silencing of CXCL12 increases the metastatic potential of mammary carcinoma cells. Oncogene 2008; 27(10): 14611471. http://dx.doi.org/10.1038/sj.onc. 1210751

[39] KOBAYASHI T, TSUDA H, MORIYA T, YAMASAKI T, KIKUCHI R et al. Expression pattern of stromal cell-derived factor- 1 chemokine in invasive breast cancer is correlated with estrogen receptor status and patient prognosis. Breast Cancer Res Treat 2010; 123(3): 733-745. http://dx.doi.org/10.1007/ $\underline{\text { s10549-009-0672-y }}$
[40] GUIL S, ESTELLER M DNA methylomes, histone codes and miRNAs: tying it all together. Int J Biochem Cell Biol 2009; $41: 87-95$. http://dx.doi.org/10.1016/j.biocel.2008.09.005

[41] HERVOUET E, CARTRON PF, JOUVENOT M, DELAGEMOURROUX R Epigenetic regulation of estrogen signaling in breast cancer. Epigenetics 2013; 8(3): 237-245. http://dx.doi. org/10.4161/epi.23790

[42] MONTENEGRO MF, SÀEZ-AYALA M, PINERO-MADRONA A, CABEZAS-HERRERA J, RODRIGUEZ-LOPEZ JN Reactivation of the Tumour Suppressor RASSF1A in Breast Cancer by Simultaneous Targeting of DNA and E2F1 Methylation. PLoS ONE 2012; 7(12): e52231. http://dx.doi. org/10.1371/journal.pone.0052231

[43] HAVIK AB, BRANDAL P, HONNE H, DAHLBACK HS, SCHEIE D et al. MGMT promoter methylation in gliomas-assessment by pyrosequencing and quantitative methylation-specific PCR. J Transl Med 2012; 10: 36. http://dx.doi. org/10.1186/1479-5876-10-36

[44] MIKESKA T, BOCK C, EL-MAARRI O, HUBNER A, EHRENTRAUT D et al. Optimization of quantitative MGMT promoter methylation analysis using pyrosequencing and combined bisulfite restriction analysis. J Mol Diagn 2007; 9(3): 368-381. http://dx.doi.org/10.2353/jmoldx.2007.060167

[45] VAN DER VAART M, PRETORIUS PJ Is the role of circulating DNA as a biomarker of cancer being prematurely overrated? Clin Biochem 2010; 43(1-2): 26-36. http://dx.doi.org/10.1016/ j.clinbiochem.2009.08.027

[46] JUNG K, FLEISCHHACKER M, RABIEN A Cell-free DNA in the blood as a solid tumor biomarker-a critical appraisal of the literature. Clin Chim Acta 2010; 411(21-22): 1611-1624. http://dx.doi.org/10.1016/j.cca.2010.07.032

[47] KORSHUNOVA Y, MALONEY RK, LAKEY N, CITEK RW, BACHER B et al. Massively parallel bisulphite pyrosequencing reveals the molecular complexity of breast cancer-associated cytosine-methylation patterns obtained from tissue and serum DNA. Genome Res 2008;18(1): 19-29. http://dx.doi. org/10.1101/gr.6883307

[48] ORDWAY JM, BUDIMAN MA, KORSHUNOVA Y, MALONEY RK, BEDELL JA et al. Identification of novel highfrequency DNA methylation changes in breast cancer. PLoS One. 2007; 2(12): e1314. http://dx.doi.org/10.1371/journal. pone. 0001314

[49] MATUSCHEK C, BOLKE E, LAMMERING G, GERBER PA, PEIPER $M$ et al. Methylated APC and GSTP1 genes in serum DNA correlate with the presence of circulating blood tumor cells and are associated with a more aggressive and advanced breast cancer disease. Eur J Med Res 2010; 15: 277-286.

[50] DIEHL F, LI M, DRESSMAN D, HE Y, SHEN D et al. Detection and quantification of mutations in the plasma of patients with colorectal tumors.Proc Natl Acad Sci U S A 2005; 102(45): 16368-16373. http://dx.doi.org/10.1073/ pnas.0507904102

[51] TERRY MB, DELGADO-CRUZATA L, VIN-RAVIN N, WU HC, SANTELLA RM DNA methylation in white blood cells: association with risk factors in epidemiologic studies. Epigenetics 2011; 6(7): 828-837. http://dx.doi.org/10.4161/ epi.6.7.16500 
[52] WIDSCHWENDTER M, APOSTOLIDOU S, RAUM E, ROTHENBACHER D, FIEGL $\mathrm{H}$ et al. Epigenotyping in peripheral blood cell DNA and breast cancer risk: a proof of principle study. PLoS One. 2008; 3(7): e2656. http://dx.doi. org/10.1371/journal.pone.0002656

[53] CHOI JY, JAMES SR, LINK PA, MC CANN SE, HONG CC et al. Association between global DNA hypomethylation in leukocytes and risk of breast cancer. Carcinogenesis 2009; 30: 1889-1897. http://dx.doi.org/10.1093/carcin/bgp143

[54] MOORE LE, PFEIFFER RM, POSCABLO C, REAL FX, KOGEVINAS $\mathrm{M}$ et al. Genomic DNA hypomethylation as a biomarker for bladder cancer susceptibility in the Spanish Bladder Cancer Study: a case-control study. Lancet Oncol 2008; 9:359-366. http://dx.doi.org/10.1016/S14702045(08)70038-X
[55] LIM U, FLOOD A, CHOI SW, ALBANES D, CROSS AJ et al. Genomic methylation of leukocyte DNA in relation to colorectal adenoma among asymptomatic women. Gastroenterology 2008; 134: 47-55. http://dx.doi.org/10.1053/ j.gastro.2007.10.013

[56] PEDERSEN KS, BAMET WR, OBERG AL, DE ANDRADE M, MATSUMOTO ME et al. Leukocyte DNA methylation signature differentiates pancreatic cancer patients from healthy controls. PLoS ONE 2011; 6: e18223. http://dx.doi. org/10.1371/journal.pone.0018223

[57] TESCHENDORFF AE, MENON U, GENTRY-MAHARAJ A, RAMUS SJ, GAYTHER SA et al. An epigenetic signature in peripheral blood predicts active ovarian cancer. PLoS ONE. 2009; 4: e8274. http://dx.doi.org/10.1371/journal. pone. 0008274 